\title{
A Diretiva Europeia de Retorno
}

\author{
João Carlos Jarochinski Silva*
}

\section{Caracterização da Diretiva}

Em 2008, os Estados europeus, grandes receptores de mão-de-obra imigrante, boa parte dela indocumentada, estabeleceram através de sua Organização Internacional, a União Europeia, uma Diretiva para o retorno forçado dos imigrantes ilegais ${ }^{1}$.

O presente artigo apresenta como objetivo principal uma crítica ao estabelecimento de regras comuns para o regresso de imigrantes não membros de países da União que, porventura, estejam em situação irregular. Apesar da Diretiva não possuir capacidade de obrigar os Estados a seguirem os seus ditames, é inquestionável que, devido ao avanço das relações jurídicas entre os países europeus, essa norma terá uma abrangência quase que total. Salientamos que essa abrangência é buscada insistentemente na própria introdução. Por esse motivo, podemos afirmar que ela marca uma posição bem nítida frente ao tema e que representará a atuação desses Estados nos próximos anos.

Tal procedimento é a primeira providência estabelecida na busca de uma regulamentação efetiva dos fluxos migratórios para os seus Estados-Membros, também estipula os procedimentos gerais a serem seguidos. Após definir o objeto, as normas versam acerca de seu âmbito de atuação, afirmando que os países só não poderão aplicá-la se houver motivo relevante para o mesmo. Outro tema é o estabelecimento de prazos para a entrada do conteúdo da Diretiva nas legislações nacionais.

Depois de definir os objetivos, a diretiva se preocupa em definir conceitos, a partir dos termos mais utilizados ao longo do texto. Chama a atenção a definição da situação irregular e as possibilidades que essa caracterização pode gerar, assim, os termos básicos são: o regresso, o afastamento e a interdição de entrada. Para o imigrante estar em uma situação considerada irregular, é necessário que ele não preencha os requisitos do acordo de Schengen².

Após essas definições de cunho mais teórico, inicia-se a previsão das garantias processuais que o imigrante possui durante o curso do processo que

* Mestre em Direito Internacional - Pesquisa relativa à imigração. Advogado membro da Comissão de Direitos Humanos da OAB/Sorocaba. 
aprecia a sua situação. Nesse ponto a Diretiva discute a forma dos atos, os recursos e as garantias do imigrante, enquanto estiver pendente a decisão de regresso, pois, quando esta for decretada, torna-se impossível a continuidade de uma relação processual com alguém que não está mais presente.

Seguindo com a exposição dos principais aspectos, a Diretiva dita as normas relativas à detenção desses imigrantes, a qual não poderá exceder o prazo de 6 meses, porém, em casos excepcionais, este prazo pode ser prorrogado por mais 12 meses. Além disso, ela determina as condições gerais de detenção, permitindo, inclusive, a detenção de menores.

Após tratar do tema da detenção, o texto estabelece as disposições finais que exigem a necessidade de relatórios, a cada três anos, sobre a aplicação das normas e, também, as regras gerais para o cumprimento desta pelos Estados-Membros.

\section{Análise da Diretiva}

A partir do exposto, é inquestionável que a Diretiva acabará gerando uma verdadeira competição pela cidadania europeia, capaz de assegurar ao imigrante um status que o impediria de ter problemas jurídicos, pois deixaria de ser indocumentado. A impressão que se tem é de que com a cidadania um mundo de oportunidades se abriria para o migrante que, assim, acabaria adquirindo o tão sonhado direito de nacionalidade, saliente-se uma nacionalidade superior: a europeia.

Apesar de não afirmar textualmente, a Diretiva coloca a imigração como a vilã, como a responsável pelos principais problemas europeus. Cite-se a disputa acirrada pelos postos de trabalho, não atentando para o fato de que quem cria realmente essa competição é o próprio mercado, interessado no barateamento de seus custos.

Assim, a cidadania passa a ser associada a um contrato de trabalho. Caso o migrante seja desejado ou necessário ao mercado, o governo garantirá a esse indivíduo sua cidadania. Vale ressaltar, que desde a escravidão nunca o conceito de cidadania sofreu tão grave ameaça, pois ele foi associado, de maneira atroz, aos interesses do sistema econômico.

A dignidade humana perde espaço para o interesse econômico, assim a regularização da situação do imigrante é vista como um prêmio, que deve ser dado aos mais capacitados para tanto.

Nesse aspecto, a Diretiva retoma a mesma realidade expressa por Abdelmalek Sayad (1998), ao discutir os acontecimentos europeus, entre as décadas de 1970 e 1980, quando os Estados desse continente buscavam atingir um nível zero de imigração. Sayad acrescenta que as discussões daquele período eram improdutivas, pois não há que se falar em negociação entre agentes tão distantes do ponto de vista econômico e político. A ideia de um contrato não é válida, já que, inquestionavelmente, essas são convenções sobre a quantidade de mão-de-obra imigrante aceita, e não objetivam discutir, em momento algum, a melhoria das condições de vida dos indivíduos.

$\mathrm{Na}$ contemporaneidade, a questão se dá de maneira mais opressora, pois a Diretiva é um instrumento unilateral, nem sequer foi dado aos países desses 
emigrantes a oportunidade de se manifestar, mesmo sabendo tratar-se de uma manifestação improdutiva, segundo Sayad (1998). Porém, acreditamos que um diálogo com essas nações demonstraria o fortalecimento das relações internacionais que poderiam convergir para um resultado mais satisfatório nesse quesito.

A Europa não percebe que uma política própria de emigração não ficará restrita à sua área de existência, já que ela gera reflexos nos países que têm parte de sua população se dirigindo para esse centro.

Essa metodologia unilateral de trabalho não se atenta ao fato de o imigrante possuir duas realidades: uma na origem e outra no destino, o que é fundamental para a compreensão do processo. Aquele indivíduo que pode ser visto como a base da pirâmide social dos países centrais pode ser, por outro lado, o indivíduo mais próximo ao pico da pirâmide social de seu país de origem, pois para aqueles que conviviam com ele no seu país de origem, ele é alguém bem-sucedido.

Felizmente, as teorias acadêmicas, diferentemente desse quase "nacionalismo europeu" expresso pelas políticas governamentais, estão atentas ao fenômeno como um todo, buscando, cada vez mais, inserir a origem como um fator de explicação da migração.

Nesse sentido, as autoridades pertencentes ao MERCOSUL rapidamente se manifestaram, de maneira contundente, contra a adoção da Diretiva, pois, apesar de impossibilitados de uma atuação mais efetiva, demonstraram uma grande insatisfação com o tratamento que seus nacionais receberão no caso de uma imigração ilegal.

A postura dos países do MERCOSUL é condizente com os princípios dos Direitos Humanos, que são fundamentais à sociedade e, também, deixa clara a mensagem de que o tema do imigrante não pode ser decidido de maneira unilateral. Eles têm a nítida percepção de que o interesse econômico está se sobrepondo ao Direito, o que os leva a clamar pela reciprocidade histórica no caso migratório e a afirmar que a responsabilidade pelo fenômeno deve ser compartida entre os países de origem, de trânsito e de destino.

Porém, a Diretiva caminha na contramão desses princípios. Através dessa postura unilateral, por parte da União Europeia, percebe-se a intenção de querer adiantar o que o fenômeno migratório causará em sua sociedade, algo que é impossível de se precisar. Por isso, não há que se criar uma imagem tão negativa do fenômeno migratório, como vem ocorrendo, apesar de em outros documentos, como o programa de Haia, o bloco afirmar que a construção de uma imagem positiva da imigração é um de seus objetivos.

Isso nos leva a pensar se os imigrantes são sujeitos de direito ou apenas mão-de-obra. Com isso, buscam-se marcos históricos para justificar a cidadania europeia que reforçam sentimentos preconceituosos em relação ao outro. Um povo possui o direito de viver em um território e outras pessoas, desde que vistas como diferentes, não.

Ressalte-se que o conceito de cidadania empregado aqui é aquele que relaciona cidadania com identidade, com o sentimento de pertencimento a uma comunidade. Jogam-se fora, portanto, todas as outras formas de cidadania, seja a cidadania revolucionária, de cunho liberal, que tanto sangue custou em sua formulação aos europeus, seja a cidadania como uma virtude republicana, de 
acordo com a qual, seja quem for, pode assumir o seu papel e lutar pela melhoria do meio social em que vive, ou, ainda, a típica concepção de cidadania dos povos de origem inglesa, sendo um pacto de contribuinte, em que o indivíduo que contribui com a manutenção do Estado por meio de impostos pode e deve cobrar do Estado uma administração que o favoreça.

Isso significa, que apesar de todo o trabalho realizado pelo imigrante e toda a sua contribuição para a vida social, ele jamais poderá ser um cidadão. Além disso, nega-se o fato, bastante óbvio, de que essa suposta identidade foi forjada pelos agentes políticos, na tentativa de afirmar a sua legitimidade sobre os seus cidadãos, diferenciando-os de outras pessoas, através de características físicas, linguísticas, religiosas, e, principalmente, culturais, garantindo, teoricamente, a essas pessoas, a capacidade de definir a sua vida política. Esqueceram-se de que as comunidades são imaginadas, na feliz expressão de Benedict Anderson (2008).

Ao tratar da formulação do conceito de cultura, Edward Said (1995, p. 12-14) relembra que

\begin{abstract}
'cultura' designa todas aquelas práticas, como as artes de descrição, comunicação e representação, que têm relativa autonomia perante os campos econômico, social e político, e que amiúde existem sob formas estéticas, sendo o prazer um de seus principais objetivos. Incluem-se aí, naturalmente, tanto o saber popular sobre partes distantes do mundo quanto o conhecimento especializado de disciplinas como a etnografia, a historiografia, a filologia, a sociologia e a história literária. [...] Em segundo lugar, cultura é um conceito que inclui um elemento de elevação e refinamento, o reservatório do melhor de cada sociedade, no saber e no pensamento, como disse Matthew Arnold na década de 1860. [...] Com o tempo, a cultura vem a ser associada, muitas vezes de forma agressiva, à nação ou ao Estado; isso 'nos' diferencia 'deles', quase sempre com algum grau de xenofobia. [...] Neste segundo sentido, a cultura é uma espécie de teatro em que várias causas políticas e ideológicas se empenham mutuamente.
\end{abstract}

Os Estados europeus começam a buscar elementos que justifiquem a criação de barreiras, fazendo com que nesse ponto a migração deixe de ser apenas uma questão econômica. Mais uma vez, em uma situação de crise, a Europa busca reafirmar os seus valores para se diferenciar, colocando, como destaca Said (1995), a cultura como um instrumento de diferenciação capaz de justificar os discursos políticos e ideológicos.

Com isso, tem início um novo modelo de integração, baseado na incorporação desses imigrantes ao modelo proposto pelos países que os recebem. Não resta dúvida que é falho, pois é baseado na agregação e assimilação do estrangeiro. Trata-se de uma perspectiva que não garante ao imigrante o direito de se manifestar como indivíduo.

Ressalte-se que a partir dessa perspectiva apenas o imigrante precisa se integrar, por mais que possua diferentes formas de manifestação popular, já o restante da sociedade não precisa trilhar o mesmo caminho. A partir deste cenário, podemos imaginar o tipo de sociedade que se deseja, já que se encontra baseada na valorização de certas atitudes em detrimento de outras e, também, com um forte resíduo etnocêntrico. 
Com isso, coloca-se o europeu como um sujeito diferenciado em relação ao imigrante e esses governos assumem a cultura como elemento utilizado para se determinar a cidadania. Mais do que cidadania, é o conceito de civilidade que é trabalhado como aquilo que diferencia o europeu do imigrante.

A cultura pode ser concebida como um processo social em que um ente, dotado de sanção e coerção, modifica a natureza dos sujeitos, cultivando-os para algo novo, no caso para ser um cidadão na sociedade europeia contemporânea. Portanto, aqueles não providos desses parâmetros culturais estariam fora dos jogos sociais que regulariam o corpo social. A União Europeia agiu para proteger sua identidade, daí as bases de uma cidadania criada na Europa.

Assim, a Europa transmite a imagem de que a concessão do visto e a naturalização são um coroamento do processo de assimilação da cultura, pois, a partir dessa identidade, o sujeito pode ser visto como um cidadão.

Esse conceito de integração está baseado no tripé Estado - Nação - Cultura. Como o econômico distingue as pessoas entre Proprietários e Proletários, estamos diante de um quadro em que o Estado, incapacitado de exercer sua política contra a classe de proprietários, cria uma nova luta de classes para se justificar perante a maior parte da população, os Proletários, que também são a maioria dos eleitores. Esta nova classe, em luta social, são os Imigrantes. Nunca se discutiu tanto sobre a Imigração e nunca o Estado esteve tão à mercê do Poder Econômico como na atualidade. Saliente-se que essa relação não ocorre por acaso.

E na tentativa de desqualificar o imigrante e sua cultura, os discursos colocam, em muitos momentos, a imigração como um dos principais responsáveis pelo aumento da delinquência, não se atentando para o fato de que o aumento da criminalidade é resultado de diversos fatores, sendo um deles o abandono dos imigrantes por parte dos órgãos oficiais. É nesse momento em que se inicia a destruição do Estado de Bem Estar Social e o culpado por isso seria o imigrante e não a ineficiência do Estado frente à economia. Assim, os problemas como a violência e o desemprego são colocados como responsabilidade de um sujeito que nem pode se manifestar politicamente.

Nesse sentido, é impressionante o discurso político francês sobre os acontecimentos de outubro e novembro de 2005, na periferia de Paris, quando o então Ministro do Interior, Nicolas Sarkozy, e o primeiro ministro, Dominique Villepin, colocaram aqueles jovens, muitos dos quais imigrantes ou filhos desses, como Escória Social.

A Europa afirma sofrer uma inundação de imigrantes, entretanto, em proporção ao número total de pessoas que circulam hoje pelo mundo, que é de aproximadamente 191 milhões, isto é, algo próximo a 3\% do total de habitantes no planeta, o movimento populacional na Europa não é tão astronômico, já que para lá se deslocam, efetivamente, apenas $10 \%$ desse número. Vale lembrar que, no início do século $\mathrm{XX}$, o número de imigrantes em proporção à população mundial era muito maior do que os números atuais.

Com a Diretiva, há a afirmação de que o ilegal é despersonalizado e visto como inimigo público, porém, o que se percebe, é um cenário em que todo o tipo de imigrante é vítima de preconceito e de xenofobia, além de tratar-se de uma mensagem estigmatizante. 
O objetivo dessas normas é atender aos anseios da sociedade europeia, que foi levada a pensar que o fator principal para o surgimento da atual crise econômica é a presença do imigrante. Não se atenta para o quadro estrutural, em que as empresas, aproveitando-se da facilidade de circulação de bens, tecnologia e serviços, acabam buscando outros pontos, onde o custo de produção seja menor, fazendo com que gere um quadro de desemprego nas nações mais abastadas e, consequentemente, com um valor salarial maior.

Mais impressionante ainda é que, devido a este fato, a questão da defesa do emprego e dos benefícios sociais se integrou aos discursos da Direita política, algo que não é muito comum em sua plataforma, enquanto setores da Esquerda acabam assumindo uma postura agressiva de não recepção de imigrantes, contrariando as suas lutas históricas em favor dos mais oprimidos.

Portanto, essa Diretiva foi a forma encontrada para proteger a Europa, mergulhada numa crise econômica, de uma imigração desenfreada. Percebe-se aqui a situação descrita por Marx, quando ele ressalta que

Num certo ponto de seu desenvolvimento, as forças produtivas materiais da sociedade entram em contradição com as relações sociais de produção existentes, ou sua expressão jurídica, com as formas de propriedade no seio das quais elas estavam, até então, caladas. Formas de desenvolvimento das formas produtivas que eram, essas relações tornam-se entraves. Então ocorre uma época de revolução social (MARX, Apud DOSSE, p. 251).

Marx não determina que tipo de revolução social ocorrerá. Porém, no caso europeu, fica evidente que essa revolução possui um viés conservador, que na busca de uma condição melhor de vida e de trabalho, encontra o inimigo não no proprietário dos bens de produção, mas no imigrante. Cria-se um conflito entre os nacionais e os estrangeiros que é reforçado pelos discursos e pelas ações estatais.

Vive-se hoje um momento de rompimento das relações tradicionais, locais e institucionais. Sem dúvida, o principal responsável por isso é o poder Econômico, capaz de dar uma dinâmica acentuada à globalização, garantindo, dessa forma, a participação em todos os campos da vida social, sem garantir, entretanto, o direito de sobrevivência para muitas pessoas.

Do ponto de vista social, esses imigrantes sujeitam-se, muitas vezes, a trabalhar com menor remuneração e em condições questionáveis, isto é, naqueles postos que a maioria dos europeus não aceitaria. Quando não é esse o caso, eles se dispõem a trabalhar nos empregos que normalmente pertenceriam aos mais jovens que, devido à demografia dos países europeus, vêm tendo sua oferta de mão-de-obra diminuída nos últimos anos. Alguns estudos afirmam que a Europa necessitará de aproximadamente 50 milhões de imigrantes até 2050 para a manutenção de suas economias ${ }^{3}$.

Portanto, deixa-se de valorizar o importante serviço que esses imigrantes prestam à economia europeia, e a questão é pensada apenas sob um viés negativo. Essa demanda terá que ser atendida de alguma forma, e o que se percebe é que 
será atendida por aqueles indivíduos que interessarem à Europa, o que é mais uma forma de opressão e preconceito, pois seleciona o imigrante.

Não resta dúvida de que toda a imigração foi selecionada, porém, a agressividade no discurso contra alguns grupos sociais é algo inédito. Não coincidentemente, essas mudanças acontecem quando o movimento migratório ocorre no sentido Sul-Norte. O discurso político começa a apresentar esse fenômeno como um problema, algo a ser combatido e até exterminado. Mais uma vez percebe-se que a integração tão propagada só existirá quando for do interesse das principais nações do mundo.

Além do mais, a Diretiva desqualifica todas as outras iniciativas europeias de regular esse fenômeno, trata-se de um verdadeiro rompimento, não existindo nexo causal entre as políticas anteriores e esta. Houve uma ruptura muito acentuada de todas as perspectivas anteriores, já que o aspecto econômico superou a defesa do ser humano.

Nesse sentido, tal texto contrariou a todas as indicações realizadas pelos órgãos envolvidos com o sistema democrático, como, por exemplo, o Conselho Europeu de Advocacia.

Não se pode alegar, como tentam os dirigentes europeus, que uma Diretiva que criminaliza o imigrante ilegal pela simples imigração seja uma garantia a esses indivíduos. A questão é que os absurdos não findam, coloca-se o imigrante em uma situação na qual o seu direito de defesa não é totalmente exercido e em que, muitas vezes, sequer há um devido processo penal.

As vias administrativas são as que possuirão maior poder sobre o imigrante, contrariando a lógica que se convencionou após os eventos traumáticos da IIa Guerra Mundial, nos quais o professor Cançado Trindade (1999, p. 51 Apud Amaral \& Perrone-Moisés) encontra o ponto de partida para uma perspectiva mais jurisdicional. Ele afirma que

ao voltar os olhos tanto para trás como para a frente, apercebemo-nos de que efetivamente houve, nestas cinco décadas de experiência acumulada nesta área desde a adoção da Declaração Universal de 1948, um claro progresso, sobretudo na jurisdicionalização da proteção internacional dos direitos humanos. Não obstante, também damos conta de que esse progresso não tem sido linear, como indica a trajetória das posições de muitos nessa área. Tem havido momentos históricos de avanços significativos, mas lamentavelmente também de alguns retrocessos, quando não deveria haver aqui espaços para estes últimos. É esse, em última análise, um domínio de proteção que não comporta retrocessos. Neste final de século, resta, certamente, um longo caminho a percorrer, tarefa para toda a vida. Trata-se, em última análise, de perseverar no ideal da construção de uma cultura universal de observância dos direitos humanos, do qual esperamos nos aproximar ainda mais, no decorrer do século XXI (...). 
A Diretiva, sem sombra de dúvidas, representa um dos retrocessos destacados pelo professor, pois, com toda a discricionariedade que garante aos agentes públicos, condena o imigrante a um limbo jurídico. A sua adoção contamina os princípios do Estado de Direito, pois não há, em todos os casos, um efetivo controle do Poder por parte do judiciário.

Esse é o ponto mais controverso da Diretiva, pois a decisão da prisão e da expulsão de um estrangeiro não é exclusivamente judicial ${ }^{4}$, o que contraria toda a lógica jurídica de um processo coerente, pautado na igualdade das partes e na isenção daquele que possui o poder de decisão. Portanto, ela não garante ao indivíduo um exercício efetivo de suas prerrogativas de direito, como por exemplo, a assistência jurídica na língua do imigrante, que deveria ser vista como uma obrigação, pela integridade de sua defesa, não o é, pois se fala em possibilidade de um intérprete, saliente-se que nem mesmo um advogado é assegurado a esse imigrante. Dessa forma, não sabemos se o Estado é de Direito ou se é o Estado de sítio, pois a única possibilidade que esse indivíduo encontra é a punição.

Bobbio (1992, p. 30), ao destacar a importância da Declaração Universal dos Direitos Humanos, ressalta que ela traduz uma tendência e pode ser concebida como universal por conta do "sentido de que os destinatários dos princípios nela contidos não são mais apenas os cidadãos deste ou daquele Estado, mas todos os homens".

Já a Diretiva assim não faz, pois não trata a todos de modo igualitário, pois para ela há grupos diferentes: os imigrantes e os cidadãos. Portanto, os Estados que se alegam liberais, contrariam os princípios basilares do Liberalismo Político. Não resta dúvida de que os direitos fundamentais devem ser regulamentados, porém, o problema ocorre quando essa regulação diminui esses direitos e, o que é pior, para apenas um setor da população.

A partir do momento em que são vistos como diferentes, os imigrantes são colocados não só em posição de inferioridade jurídica, mas também de inferioridade social, eles passam a ser vistos como um excedente, e como tal podem ser descartados.

Essa postura não colabora com o setor mais necessitado da população e nem favorece a concorrência entre as pessoas para o desenvolvimento econômico; mesmo numa perspectiva capitalista, a falta de liberdade para esse imigrante se torna um obstáculo à sua contratação, fazendo com que ele não possa ser empregado por conta de sua condição, o que elimina a sua possibilidade de concorrer em igualdade de condições com os nacionais. Dessa forma, a possibilidade de livremente disputar uma vaga, de oferecer os seus serviços por conta de sua capacidade ou, ainda, de aceitar o menor preço de sua mão-deobra, é uma enorme contradição com os princípios do Liberalismo.

Corroborando tal ideia, coloca-se a questão do regresso, tentando criar uma analogia com a ideia de retorno; daí advém o próprio nome da Diretiva, que muitas vezes trabalha com a repatriação, mas o objetivo central é a expulsão. No texto percebe-se que os Estados europeus não estão muito interessados no local em que deixarão esse expulso: o importante é se livrar do mesmo.

Nesse sentido, o texto incentiva a auto-deportação ${ }^{5}$, não se atentando para o fato de esta atitude ser uma das mais claras manifestações da servidão voluntária de um sujeito ao Estado, já que não se oferece ao indivíduo uma série de garantias, mas se exige que ele tenha uma postura servil frente a esse Estado. 
O Estado possui, através de sua soberania, a possibilidade de definir quem pode entrar em seu território. Entretanto, ele não pode alegar que isso constitui uma garantia ao próprio imigrante. A auto-deportação ou a expulsão jamais podem ser consideradas garantias, pois se assim o fossem, que motivo explicaria o fato de ele ter deixado o local de origem?!

Outra questão séria que se apresenta é o fato de o imigrante poder ser preso ${ }^{6}$. A Diretiva fala que a mesma só existe para efeitos de afastamento que, segundo explicação do próprio texto, é a execução da obrigação de regresso, ou seja, o transporte físico para fora do país.

Portanto, não há razão penal para essa prisão num primeiro momento, trata-se de uma prisão de cunho administrativo a fim de averiguar a situação do imigrante, para uma possível decretação de regresso. Porém, mesmo com esse cunho essencialmente administrativo, de caracterização de uma situação, o imigrante pode permanecer preso por seis meses, o que é um exagero para as devidas providências legais. Com isso podemos afirmar que não há proporcionalidade e objetivo para essa pena de reclusão. Trata-se somente de uma privação de liberdade, decretada pela administração sem um prazo legal estabelecido e, sequer, a revisão da mesma por um órgão jurisdicional.

Assim, ela acaba se configurando o bis in idem, pois, juntamente com o afastamento e a interdição de entrada, pune o indivíduo mais de uma vez, pelo mesmo fato típico que é o de emigrar sem um documento que o autorize .

Mais do que isso, há a previsão do encarceramento de menores desacompanhados ${ }^{7}$ para posterior expulsão, o que, já não bastasse o absurdo dessa medida ao igualar menores e adultos, contraria o Tratado do Direito das Crianças, do qual os países europeus são signatários. Tal fato explicita a falta de coerência desses que parecem se esquecer de todo o corpo de normas existente.

A falácia de que essa mudança venha representar uma garantia vem também do fato de que em alguns países, antes desse documento, não existia limite de tempo para a prisão de imigrantes e que agora o prazo máximo é de 18 meses ${ }^{8}$. Percebe-se aqui mais uma tentativa de construção de um discurso incapaz de modificar a realidade posta.

\section{Conclusão}

Através desse relato, percebemos as nefastas consequências que a Diretiva pode representar para os direitos humanos. A Europa perdeu uma oportunidade histórica de estabelecer um novo marco ao adotar uma política única de Imigração atenta aos princípios mais valiosos dos Direitos Humanos.

A verdade é que caminhamos para a questão de quanto de injustiça será aceita socialmente contra o imigrante. O resultado dessa Diretiva é a criminalização da pobreza e a institucionalização do Preconceito. Estamos prestes a assistir a criação de um novo Apartheid. 


\section{Notas}

1- Anexamos, ao final do texto, um fragmento da Diretiva com o objetivo de auxiliar o leitor a compreender as principais questões que serão aqui abordadas. Vale ressaltar que nesse fragmento se atentou para as normas principais, isto é, aquelas que efetivamente afetam os imigrantes, deixando de lado aspectos meramente formais e burocráticos da entrada em vigor do texto, bem como as diretrizes iniciais e os últimos artigos.

2 - O Acordo de Schengen, assinado entre a Alemanha, a Bélgica, a França, o Luxemburgo e os Países Baixos, em 14 de Junho de 1985, visa suprimir gradualmente os controles nas fronteiras comuns e instaurar um regime de livre circulação para todos os nacionais dos Estados signatários, dos outros Estados da Comunidade ou de países terceiros.

A convenção de Schengen completa o acordo e define as condições de aplicação e as garantias de realização desta livre circulação. Foi assinada em 19 de Junho de 1990 pelos referidos cinco Estados-Membros, mas só entrou em vigor em 1995.

O Acordo e a Convenção de Schengen, as regras adotadas com base nestes dois textos e os acordos conexos constituem o «acervo de Schengen». Desde 1999, o acervo de Schengen foi integrado no quadro institucional e jurídico da União Europeia por força de um protocolo anexo ao Tratado de Amsterdã. (http://europa.eu/scadplus/glossary/schengen_agreement_pt.htm - acesso dia 08/09/2009 às 23h 14).

3 - Este estudo baseia as próprias perspectivas europeias sobre o tema como se pode conferir em http://eur-lex.europa.eu/LexUriServ/LexUriServ.do?uri=COM:2007:0780:FIN:PT:DOC-acessado dia 08/09/2009, às 23h 32).

4 - Vide artigo 15으, item 2 da Diretiva.

5 - Vide artigo 70 da Diretiva.

6 - Vide artigo 15음 da Diretiva.

7 - Vide artigo 170 da Diretiva.

8 - Vide artigo 15ㅇ.

\section{Referências}

AMARAL JÚNIOR, Alberto; PERRONE-MOISÉS, Cláudia (orgs.). O Cinquentenário da Declaração Universal dos Direitos do Homem. São Paulo: Edusp, 1999.

ANDERSON, Benedict. Comunidades Imaginadas. São Paulo: Companhia das Letras, 2008.

BOBBIO, Norberto. A Era dos Direitos. Rio de Janeiro: Campus, 1992.

DOSSE, François. A História. Bauru (SP): EDUSC, 2003.

SAID, Edward. Cultura e imperialismo. São Paulo: Cia das Letras, 1995.

SAYAD, Abdelmalek. A Imigração. São Paulo: Edusp, 1998. 


\title{
DIRETIVA 2008/115/CE DO PARLAMENTO EUROPEU E DO CONSELHO de 16 de Dezembro de 2008
} Relativa a normas e procedimentos comuns nos EstadosMembros para o regresso de nacionais de países terceiros em situação irregular ${ }^{1}$

\section{DISPOSIÇÕES GERAIS}

\begin{abstract}
Artigo 1.으
Objeto

A presente diretiva estabelece normas e procedimentos comuns a aplicar nos Estados Membros para o regresso de nacionais de países terceiros em situação irregular, com observância dos direitos fundamentais enquanto princípios gerais do direito comunitário, bem como do direito internacional, incluindo as obrigações em matéria de proteção dos refugiados e dos direitos humanos.
\end{abstract}

\section{Artigo 2.9}

Âmbito de aplicação

1. A presente diretiva é aplicável aos nacionais de países terceiros em situação irregular no território de um Estado-Membro.

2. Os Estados-Membros podem decidir não aplicar a diretiva aos nacionais de países terceiros que:

Sejam objeto de uma recusa de entrada, de acordo com o artigo 13 do Código das Fronteiras Schengen, ou sejam detidos ou interceptados pelas autoridades competentes por ocasião da passagem ilegal das fronteiras externas terrestres, marítimas ou aéreas de um Estado-Membro e que não tenham obtido posteriormente uma autorização ou um direito de permanência nesse Estado-Membro;

Sejam objeto de uma sanção penal que preveja o seu regresso ou como consequência de uma sanção penal, em conformidade com o direito interno, ou sejam objeto de um processo de extradição.

3. A presente diretiva não se aplica aos beneficiários do direito comunitário à livre circulação definidos no no 5 do artigo 2 do Código das Fronteiras Schengen.

\section{Artigo 3은}

\section{Definições}

Para efeitos da presente diretiva, entende-se por:

a) "Nacional de país terceiro”, uma pessoa que não seja cidadão da União, na acepção do no 1 do artigo 17을 do Tratado, e que não beneficie do direito comunitário à livre circulação, tal como definido no no 5 do artigo 2 o do Código das Fronteiras Schengen;

b) "Situação irregular", a presença, no território de um Estado-Membro, de um nacional de país terceiro que não preencha, ou tenha deixado de preencher, as condições de entrada estabelecidas no artigo 5o do Código das Fronteiras Schengen ou outras condições aplicáveis à entrada, permanência ou residência nesse Estado-Membro;

c) "Regresso", o processo de retorno - quer em cumprimento voluntário de uma obrigação de regresso, quer forçado: ao país de origem, ou a um país de trânsito, em conformidade com acordos de readmissão comunitários ou bilaterais ou com outros convênios, ou a outro país terceiro, para o qual o nacional de país terceiro em causa decida regressar voluntariamente e no qual seja aceito;

1 - Fonte: Jornal Oficial da União Europeia do dia 24/12/2008. 
d)"Decisão de regresso", uma decisão ou ato administrativo ou judicial que estabeleça ou declare a situação irregular de um nacional de país terceiro e imponha ou declare a obrigação de regresso;

e)"Afastamento", a execução da obrigação de regresso, ou seja, o transporte físico para fora do país;

f)"Interdição de entrada", a decisão ou ato administrativo ou judicial que proíbe a entrada e a permanência no território dos Estados-Membros durante um período determinado, e que acompanha uma decisão de regresso;

g) "Risco de fuga", a existência de razões, baseadas em critérios objetivos definidos por lei, para crer, num caso concreto, que o nacional de país terceiro objeto de um procedimento de regresso poderá fugir;

h)"Partida voluntária", o cumprimento da obrigação de regressar no prazo fixado para o efeito na decisão de regresso;

i)"Pessoas vulneráveis", menores, menores não acompanhados, pessoas com deficiência, idosos, grávidas, familias monoparentais com filhos menores e pessoas que tenham sido vítimas de tortura, violação ou outras formas graves de violência psicológica, física ou sexual.

\section{Artigo 4.으}

\section{Disposições mais favoráveis}

1. A presente diretiva não prejudica a aplicação de disposições mais favoráveis constantes de:

a) Acordos bilaterais ou multilaterais celebrados entre a Comunidade, ou entre a Comunidade e os seus Estados-Membros, e um ou mais países terceiros;

b) Acordos bilaterais ou multilaterais celebrados entre um ou mais Estados-Membros e um ou mais países terceiros.

2. A presente diretiva não prejudica a aplicação de quaisquer disposições previstas no acervo comunitário em matéria de imigração e asilo.

3. A presente diretiva não prejudica o direito dos Estados-Membros de adotarem ou manterem disposições mais favoráveis relativamente às pessoas abrangidas pelo seu âmbito de aplicação, desde que compatíveis com o disposto na presente diretiva.

4. No que respeita aos nacionais de países terceiros excluídos do âmbito de aplicação da presente diretiva nos termos da alínea a) do no 2 do artigo 2ㅇ, os Estados-Membros devem: - assegurar que o seu tratamento e o nivel de proteção não sejam menos favoráveis que os previstos nos nos 4 e 5 do artigo 8o (restrições à utilização de medidas coercivas), no primeiro travessão do $n-2$ do artigo 9 - (adiamento do afastamento), nos segundo e quarto travessões do $n^{\circ} 1$ do artigo 14ㅇ (cuidados de saúde urgentes e tomada em consideração das necessidades das pessoas vulneráveis) e nos artigos 16 e 17으 (condições de detenção), e - respeitar o princípio da não-repulsão.

\section{Artigo 50}

Não-repulsão, interesse superior da criança, relações familiares e estado de saúde.

Ao aplicarem a presente diretiva, os Estados-Membros devem ter em devida conta o seguinte:

a) $O$ interesse superior da criança;

b) A vida familiar;

c) O estado de saúde do nacional de país terceiro em causa; e respeitar o princípio da não-repulsão.

\section{TERMO DA SITUAÇÃO IRREGULAR}

\section{Artigo 6.}

\section{Decisão de regresso}

1. Sem prejuízo das exceções referidas nos nos 2, 3, 4 e 5, os Estados-Membros emitem uma decisão de regresso relativamente a qualquer nacional de país terceiro que se encontre em situação irregular no seu território.

2. Os nacionais de países terceiros em situação irregular no território de um Estado-Membro que sejam detentores de um título de residência válido ou de outro título, emitido por outro Estado-Membro, que Ihes confira direito de permanência devem estar obrigados a deslocar-se imediatamente para esse Estado-Membro. Em caso de incumprimento desta exigência pelo nacional de país terceiro, ou se for necessária a partida imediata do nacional de país terceiro por razões de segurança nacional ou de ordem pública, aplica-se o no 1 . 
3. Os Estados-Membros podem abster-se de emitir uma decisão de regresso em relação a um nacional de país terceiro que se encontre em situação irregular no seu território, se esse nacional for aceito por outro Estado-Membro no âmbito de acordos ou convênios bilaterais existentes à data da entrada em vigor da presente diretiva. Nesse caso, o Estado-Membro que aceitou o nacional do país terceiro em causa aplica o $n$ ㅇ 1 .

4. Os Estados-Membros podem, a qualquer momento, decidir conceder uma autorização de residência autônoma ou de outro tipo que por razões compassivas, humanitárias ou outras, confira direito de permanência a um nacional de país terceiro em situação irregular no seu território. Neste caso, não deve ser emitida qualquer decisão de regresso. Nos casos em que já tiver sido emitida uma decisão de regresso, esta deve ser retirada ou suspensa durante o período de vigência da autorização de residência ou de outra autorização que confira direito de permanência.

5. Se um nacional de país terceiro em situação irregular no território de um Estado-Membro tiver pendente um processo de renovação do seu título de residência ou de outro título que lhe confira direito de permanência, esse Estado-Membro pondera a hipótese de se abster de emitir uma decisão de regresso até que o processo esteja concluído, sem prejuízo do disposto no $n$ o 6 .

6. A presente diretiva não obsta a que os Estados-Membros tomem a decisão de pôr termo a uma permanência legal, juntamente com uma decisão de regresso e/ou uma ordem de afastamento, e/ou uma interdição de entrada, no âmbito de uma decisão ou ato administrativo ou judicial previsto no seu direito interno, sem prejuízo das garantias processuais disponíveis ao abrigo do Capítulo III da presente diretiva e de outras disposições pertinentes do direito comunitário e do direito nacional.

\section{Artigo 70}

Partida voluntária

1. A decisão de regresso deve prever um prazo adequado para a partida voluntária, compreendido entre sete dias e trinta dias, sem prejuízo das derrogações previstas nos nos 2 e 4 . Os Estados-Membros podem determinar na sua legislação nacional que esse prazo só é concedido na sequência da apresentação de um pedido pelo nacional de país terceiro em causa. Nesse caso, os Estados-Membros informam os nacionais do país terceiro em causa sobre a possibilidade de apresentar tal pedido.

o prazo acima previsto não exclui a possibilidade de os nacionais de países terceiros em causa partirem antes de terminado esse prazo.

2. Se necessário, os Estados-Membros estendem o prazo previsto para a partida voluntária por um período adequado, tendo em conta as especificidades do caso concreto, tais como a duração da permanência, a existência de filhos que frequentam a escola e a existência de outros membros da família e de laços sociais.

3. Podem ser impostas determinadas obrigações para evitar o risco de fuga, designadamente a apresentação periódica às autoridades, o depósito de uma caução adequada, a apresentação de documentos ou a obrigação de permanecer em determinado local durante o referido período.

4. Se houver risco de fuga ou se tiver sido indeferido um pedido de permanência legal por ser manifestamente infundado ou fraudulento, ou se a pessoa em causa constituir um risco para a ordem ou segurança pública ou para a segurança nacional, os Estados-Membros podem não conceder um prazo para a partida voluntária, ou conceder um prazo inferior a sete dias.

\section{Artigo 8.ㅇ}

\section{Afastamento}

1. Os Estados-Membros tomam todas as medidas necessárias para executar a decisão de regresso se não tiver sido concedido qualquer prazo para a partida voluntária, nos termos do artigo 7ํㅡ, ou se a obrigação de regresso não tiver sido cumprida dentro do prazo para a partida voluntária concedido em conformidade com o artigo 70 .

2. Se o Estado-Membro tiver concedido um prazo para a partida voluntária em conformidade com o artigo 7으, a decisão de regresso só pode ser executada uma vez terminado esse prazo, a não ser que durante esse prazo surja um risco, tal como referido no no 4 do artigo 70 . 
3. Os Estados-Membros podem adotar uma decisão ou ato administrativo ou judicial separados para ordenar o afastamento.

4. Se os Estados-Membros utilizarem - como último recurso-medidas coercivas para impor o afastamento de um nacional de país terceiro que a ele resista, tais medidas devem ser proporcionadas e a utilização da força não deve ultrapassar os limites do razoável. Essas medidas devem ser executadas em conformidade com a legislação nacional, de acordo com os direitos fundamentais e no devido respeito pela dignidade $e$ integridade física do nacional de país terceiro em causa.

5. Nas operações de afastamento por via aérea, os Estados-Membros devem ter em conta as Orientações comuns em matéria de disposições de segurança nas operações conjuntas de afastamento por via aérea anexas à Decisão 2004/573/CE.

6. Os Estados-Membros devem prever um sistema eficaz de controle dos regressos forçados.

\section{Artigo 90}

Adiamento do afastamento

1. Os Estados-Membros adiam o afastamento nos seguintes casos:

- o afastamento representa uma violação do princípio da não-repulsão, ou

- durante a suspensão concedida nos termos do no 2 do artigo 13‥

2. Os Estados-Membros podem adiar o afastamento por um período considerado adequado tendo em conta as circunstâncias especificas do caso concreto. Os Estados-Membros devem em particular ter em conta:

- o estado físico ou a capacidade mental da pessoa;

- razões técnicas, nomeadamente falta de capacidade de transporte ou afastamento falhado devido à ausência de identificação.

3. Caso o afastamento seja adiado nas condições estabelecidas nos nos 1 e 2, podem ser impostas ao nacional de país terceiro em causa as obrigações previstas no № 3 do artigo 70 .

\section{Artigo 10은}

\section{Regresso e afastamento de menores não acompanhados}

1. Antes de uma decisão de regresso aplicável a um menor não acompanhado, é concedida assistência pelos organismos adequados para além das autoridades que executam o regresso, tendo na devida conta o interesse superior da criança.

2. Antes de afastar um menor não acompanhado para fora do seu território, as autoridades do EstadoMembro garantem que o menor é entregue no Estado de regresso a um membro da sua família, a um tutor designado ou a uma estrutura de acolhimento adequada.

\section{Artigo 11은}

Interdição de entrada

1. As decisões de regresso são acompanhadas de uma interdição de entrada:

- se não tiver sido concedido qualquer prazo para a partida voluntária, ou

- se a obrigação de regresso não tiver sido cumprida.

Nos outros casos, as decisões de regresso podem ser acompanhadas de uma interdição de entrada.

2. A duração da interdição de entrada é determinada tendo em devida consideração todas as circunstâncias relevantes do caso concreto não devendo em princípio ser superior a cinco anos. Essa duração pode ser superior a cinco anos se o nacional de país terceiro constituir uma ameaça grave à ordem pública, à segurança pública ou à segurança nacional.

3. Os Estados-Membros devem ponderar a retirada ou a suspensão de uma interdição de entrada, se um nacional de país terceiro que seja objeto de uma interdição de entrada, emitida nos termos do segundo parágrafo do no 1, provar que deixou o território de um Estado-Membro em plena conformidade com uma decisão de regresso.

As vítimas do tráfico de seres humanos a quem tenha sido concedido um título de residência, nos termos da Diretiva 2004/81/CE do Conselho, de 29 de Abril de 2004, relativa ao título de residência concedido aos nacionais de países terceiros que sejam vítimas do tráfico de seres humanos ou objeto de uma ação de auxílio 
à imigração ilegal, e que cooperem com as autoridades competentes, não são objeto de uma interdição de entrada, sem prejuízo do segundo travessão do primeiro parágrafo do no 1 , desde que não representem uma ameaça à ordem pública, à segurança pública ou à segurança nacional.

Os Estados-Membros podem abster-se de emitir, retirar ou suspender uma interdição de entrada em determinados casos concretos, por razões humanitárias.

Os Estados-Membros podem retirar ou suspender uma interdição de entrada em determinados casos concretos ou em determinadas categorias de casos por outras razões.

4. Ao ponderarem a emissão de uma autorização de residência ou de outro título que confira direito de permanência a um nacional de país terceiro objeto de uma interdição de entrada emitida por outro Estado-Membro, os Estados-Membros consultam primeiro o Estado-Membro que emitiu a interdição de entrada e têm em conta os seus interesses, em conformidade com o disposto no artigo 25으 da Convenção de Aplicação do Acordo de Schengen.

5. O disposto nos nㅗ 1 a 4 é aplicável sem prejuízo do direito de solicitar num dos Estados-Membros proteção internacional, tal como definida na alínea a) do artigo 20 da Diretiva 2004/83/CE.

\section{GARANTIAS PROCESSUAIS}

\section{Artigo 12ㅇ}

Forma

1. As decisões de regresso e, se tiverem sido emitidas, as decisões de interdição de entrada e as decisões de afastamento são emitidas por escrito e contêm as razões de fato e de direito, bem como informações acerca das vias de recurso disponíveis.

As informações sobre as razões de fato podem ser limitadas caso o direito nacional permita uma restrição ao direito de informação, nomeadamente para salvaguardar a segurança nacional, a defesa, a segurança pública e a prevenção, investigação, detecção e repressão de infrações penais.

2. A pedido, os Estados-Membros fornecem uma tradução escrita ou oral dos principais elementos das decisões relacionadas com o regresso, a que se refere o $n$ - 1 , nomeadamente informações sobre as vias de recurso disponíveis, numa língua que o nacional de país terceiro compreenda ou se possa razoavelmente supor que compreende.

3. Os Estados-Membros podem não aplicar o disposto no no 2 às pessoas que tenham entrado ilegalmente no território de um Estado-Membro e que não tenham obtido, subsequentemente, uma autorização ou um direito de permanência nesse Estado-Membro.

Nesse caso, as decisões relacionadas com o regresso, a que se refere o $n$ o 1, são notificadas através do formulário normalizado previsto nos termos da legislação nacional.

Os Estados-Membros facultam folhetos informativos gerais que expliquem os principais elementos do formulário normalizado em pelo menos cinco das línguas mais frequentemente utilizadas ou compreendidas pelos migrantes ilegais que entram nesse Estado-Membro.

\section{Artigo 13은}

\section{Recursos}

1. O nacional de país terceiro em causa deve dispor de recurso efetivo contra decisões relacionadas com o regresso, a que se refere o no 1 do artigo 12으, ou da possibilidade de requerer a sua reapreciação, perante uma autoridade judicial ou administrativa competente ou um órgão competente composto por membros imparciais que ofereçam garantias de independência.

2. A autoridade ou o órgão acima mencionados são competentes para reapreciar as decisões relacionadas com o regresso, a que se refere o $n-1$ do artigo 12ㅇ, incluindo a possibilidade de suspender temporariamente a sua execução, a menos que a suspensão temporária já seja aplicável ao abrigo da legislação nacional.

3. O nacional de país terceiro em causa pode obter a assistência e a representação de um advogado e, se necessário, os serviços de um intérprete.

4. Os Estados-Membros asseguram a concessão de assistência jurídica e/ou representação gratuitas, a pedido, nos termos da legislação nacional pertinente ou da regulamentação relativa à assistência jurídica e podem prever que a concessão dessa assistência ou representação gratuitas está sujeita às condições 
previstas nos nos 3 a 6 do artigo 15o da Diretiva 2005/85/CE relativa a normas mínimas aplicáveis ao procedimento de concessão e retirada do estatuto de refugiado nos Estados-Membros.

\section{Artigo 14은}

\section{Garantias na pendência do regresso}

1. À exceção da situação prevista nos artigos 16 e 17으, os Estados-Membros asseguram que sejam tidos em conta, tanto quanto possivel, os seguintes princípios em relação aos nacionais de países terceiros durante o prazo para a partida voluntária concedido nos termos do artigo $7^{\circ}$ e durante os períodos de adiamento do afastamento previstos no artigo 9 o:

- é mantida a unidade familiar com os membros da família presentes no seu território;

- são facultados cuidados de saúde urgentes e o tratamento básico de doenças;

- é concedido aos menores acesso ao sistema de ensino básico, consoante a duração da sua permanência;

- são tidas em conta as necessidades específicas das pessoas vulneráveis.

2. Os Estados-Membros confirmam por escrito às pessoas referidas no ํㅡ 1, em conformidade com a legislação nacional, que o prazo concedido para a partida voluntária foi prorrogado nos termos do no 2 do artigo 70 ou que a decisão de regresso não será temporariamente executada.

\section{DETENÇÃO PARA EFEITOS DE AFASTAMENTO}

\section{Artigo 150 \\ Detenção}

1. A menos que no caso concreto possam ser aplicadas com eficácia outras medidas suficientes mas menos coercivas, os Estados-Membros só podem manter detido um nacional de país terceiro objeto de procedimento de regresso, a fim de preparar o regresso e/ou efetuar o processo de afastamento, nomeadamente quando:

- houver risco de fuga, ou

- o nacional de país terceiro em causa evitar ou entravar a preparação do regresso ou o procedimento de afastamento.

A detenção tem a duração menor possivel, sendo apenas mantida enquanto o procedimento de afastamento estiver pendente e for executado com a devida diligência.

2. A detenção é ordenada por autoridades administrativas ou judiciais.

A detenção é ordenada por escrito com menção das razões de fato e de direito.

Quando a detenção tiver sido ordenada por autoridades administrativas, os Estados-Membros:

- prevêem o controle jurisdicional célere da legalidade da detenção, a decidir o mais rapidamente possível a contar do início da detenção, ou

- concedem ao nacional de país terceiro em causa o direito de intentar uma ação através da qual a legalidade da sua detenção faça objeto de controle jurisdicional célere, a decidir o mais rapidamente possível a contar da instauração da ação aplicável; neste caso, os Estados-Membros informam imediatamente o nacional de país terceiro em causa sobre a possibilidade de apresentar esse requerimento.

O nacional de país terceiro em causa é libertado imediatamente se a detenção for ilegal.

3. Em todo o caso, a detenção é reapreciada a intervalos razoáveis, quer a pedido do nacional de país terceiro em causa, quer ex officio. No caso de períodos de detenção prolongados, as reapreciações são objeto de fiscalização por uma autoridade judicial.

4. Quando, por razões de natureza jurídica ou outra ou por terem deixado de se verificar as condições enunciadas no n. 1 , se afigure já não existir uma perspectiva razoável de afastamento, a detenção deixa de se justificar e a pessoa em causa é libertada imediatamente.

5 . A detenção mantém-se enquanto se verificarem as condições enunciadas no no 1 e na medida do necessário para garantir a execução da operação de afastamento. Cada Estado-Membro fixa um período limitado de detenção, que não pode exceder os seis meses.

6. Os Estados-Membros não podem prorrogar o período a que se refere o $n-4$, exceto por um período limitado que não exceda outros doze meses de acordo com a lei nacional nos casos em que, independentemente de 
todos os esforços razoáveis que tenham envidado, se preveja que a operação de afastamento dure mais tempo, por força de:

- falta de cooperação do nacional do país terceiro em causa, ou

- atrasos na obtenção da documentação necessária junto de países terceiros.

\section{Artigo 16은}

\section{Condições de detenção}

1. Regra geral, a detenção tem lugar em centros de detenção especializados. Se um Estado-Membro não tiver condições para assegurar aos nacionais de países terceiros a sua detenção num centro especializado e tiver de recorrer a um estabelecimento prisional, os nacionais de países terceiros colocados em detenção ficam separados dos presos comuns.

2. Os nacionais de países terceiros detidos são autorizados, a pedido, a contatar oportunamente os seus representantes legais, familiares e autoridades consulares competentes.

3. Deve atribuir-se especial atenção à situação das pessoas vulneráveis e ser dispensados cuidados de saúde urgentes e o tratamento básico de doenças.

4. As organizações e os órgãos nacionais e internacionais relevantes e as organizações e os órgãos não governamentais competentes devem ter a possibilidade de visitar os centros de detenção a que se refere 0 no 1 , na medida em que estejam a ser utilizados para a detenção de nacionais de países terceiros de acordo com o presente capítulo. Essas visitas podem ser sujeitas à autorização.

5. Aos nacionais de países terceiros detidos são sistematicamente fornecidas informações que expliquem as regras aplicadas no centro de detenção e indiquem os seus direitos e obrigações, nomeadamente o seu direito, de acordo com o direito nacional, a contatarem as organizações e órgãos referidos no no 4 .

\section{Artigo 17은}

Detenção de menores e famílias

1. Os menores não acompanhados e as famílias com menores só podem ser detidos em último recurso e por um período adequado que seja o mais curto possível.

2. As famílias detidas na pendência do afastamento ficam alojadas em locais separados que garantam a devida privacidade.

3. Os menores detidos devem ter a possibilidade de participar em atividades de lazer, nomeadamente em jogos e atividades recreativas próprias da sua idade, e, em função da duração da permanência, devem ter acesso ao ensino.

4. Os menores não acompanhados beneficiam, tanto quanto possivel, de alojamento em instituições dotadas de pessoal e instalações que tenham em conta as necessidades de pessoas da sua idade.

5. No contexto da detenção de menores na pendência do afastamento, o interesse superior da criança constitui uma consideração primordial.

\section{Artigo 18은}

\section{Situações de emergência}

1. Caso um número excepcionalmente elevado de nacionais de países terceiros que devam ser objeto de uma operação de regresso sobrecarregue de forma imprevista a capacidade dos centros de detenção de um Estado-Membro ou o seu pessoal administrativo ou judicial, o Estado-Membro em causa, pode, enquanto persistir a situação excepcional, autorizar o controle jurisdicional por períodos superiores aos previstos no no 2 do artigo 15 e tomar medidas urgentes em relação às condições de detenção, em derrogação das previstas no no 1 do artigo 16ㅇ e no no 2 do artigo 17‥

2. O Estado-Membro em causa informa a Comissão sempre que recorra a medidas excepcionais desse tipo. Deve igualmente informar a Comissão tão logo os motivos que conduziram à aplicação dessas medidas deixem de existir.

3. O presente artigo em nada prejudica o dever geral dos Estados-Membros de tomarem todas as medidas adequadas, de caráter geral ou específico, para assegurarem o cumprimento das obrigações decorrentes da presente diretiva. 
